\title{
ANALISIS PENGARUH KOMPETENSI MANAJER TERHADAP PRAKTIK AKUNTANSI KEUANGAN PADA USAHA KECIL DAN MENENGAH DI KOTA JAMBI
}

\author{
Oleh: \\ Ilham Wahyudi \\ (Dosen Program Studi Akuntansi Universitas Jambi)
}

\begin{abstract}
The objective of this research is to know the influence of manager competency to financial accounting practice in small and middle industries in Jambi.In the theoretical frame work, manager knowledge in accounting as a business language could improve the ability to analysis business decision. It is supported in empiric by last research that are four factors which influence in using financial accounting information, they consist of a). Age of the company, b). The education of company owner, c). The accounting practice which has been following and d). Industri sector where is company operation. While that financial accounting information getting from financial statement which is output from financial accounting application so the hypothesis is that the manager competency which is measurement in aducation level and the accounting practice which has been following have the influence to application of financial accounting. The methode used in this research is quantitative analysis. Tool of analysis data used diskriminant analysis in two category. The result of this research show that, competency from 77 managers of small and middle industri in Jambi which are use as respondent of this research, have positive influence to financial accounting practice, although the influence wasn't too significance.
\end{abstract}

Keywords : Competency, Manager, Financial Accounting Practice.

\section{Latar Belakang}

Perusahaan kecil dan menengah mempunyai andil yang sangat besar dalam perekonomian suatu negara. Perkembangan dan pertumbuhan industri kecil dan menengah telah menjadi motor penggerak yang penting bagi pertumbuhan ekonomi di negara-negara berkembang. Perusahan kecil dan menengah mampu menyerap tenaga kerja dalam jumlah yang besar sehingga berpengaruh pula terhadap pendapatan nasional suatu negara.

Di Indonesia sendiri, perhatian pemerintah terhadap usaha kecil dan menengah ini cukup besar. Hal ini dapat dilihat dalam sidang APEC di Bogor tanggal 15 November 1994, di mana perusahaan kecil menjadi salah satu agenda pembicaraan. Hal ini mengindikasikan bahwa usaha kecil dan menengah memegang peranan penting dalam perekonomian terutama bila dikaitkan dengan jumlah tenaga kerja yang mampu diserap usaha kecil dan menengah, pemerataan pendapatan melalui kesempatan berusaha, pengembangan daerah pedesaan, mengembangkan pembangunan antar daerah, meningkatkan investasi dan mengembangkan jiwa kewirausahaan serta kontribusinya terhadap pendapatan nasional (Tambunan, 2001). Hal ini dapat dilihat dari meningkatnya ekspor komoditi non migas terutama pada sektor usaha rumah tangga yang juga banyak menyerap tenaga kerja seperti tekstil dan garmen, hasil kerajinan, sepatu dan meubel. 
Tabel 1

Data Pendapatan Domestik Bruto dan Penyerapan Tenaga Kerja KUKM pada Tahun 2005 dan 2006

\begin{tabular}{|c|c|c|c|c|}
\hline \multirow{2}{*}{} & \multicolumn{2}{|c|}{2005} & \multicolumn{2}{c|}{2006} \\
\cline { 2 - 5 } & PDB & $\begin{array}{c}\text { Penyerapan } \\
\text { Tenaga Kerja }\end{array}$ & PDB & $\begin{array}{c}\text { Penyerapan } \\
\text { Tenaga Kerja }\end{array}$ \\
\hline Usaha Kecil & $1.053 .343,2$ & 78.994 .872 & $1.257 .654,8$ & 80.933 .384 \\
\hline $\begin{array}{c}\text { Usaha } \\
\text { Menengah }\end{array}$ & $437.718,7$ & 4.238 .921 & $521.090,9$ & 4.483 .109 \\
\hline
\end{tabular}

Sumber : Data Kementrian KUKM, 2006

Menurut data Kementerian Koperasi dan Pengusaha Kecil dan Menengah seperti yang terlihat dalam tabel 1.1, jumlah penyerapan tenaga kerja pada perusahaan kecil pada tahun 2005 adalah sebanyak 78.994 .872 juta orang, sedangkan perusahaan menengah menampung tenaga kerja 4.238 .921 juta orang. Pada tahun 2006 usaha kecil menyerap lebih kurang 80.933.384 juta tenaga kerja, sedangkan usaha menengah menyerap lebih kurang 4.483.109 juta orang tenaga kerja. Hal ini disebabkan bidang usaha, terutama perusahaan kecil yang bersifat padat karya dan biasanya tersebar hingga ke pelosok daerah. Peran perusahaan kecil dan menengah ini pun terlihat nyata dalam kontribusinya terhadap Pendapatan Domestik Bruto (PDB) Indonesia. Pada tahun 2005 kontribusi perusahan kecil terhadap total PDB sebesar 1.053.343,2 dan meningkat menjadi $1.257 .654,8$ pada tahun 2006 , sedangkan kontribusi perusahaan menengah terhadap total PDB pada tahun 2005 sebesar 437.718,7 dan meningkat menjadi 521.090,9 pada tahun 2006. Selain itu, pertumbuhan usaha kecil dan menengah mendorong perkembangan komunitas dan ekonomi lokal.

Uraian di atas menunjukkan, bahwa usaha kecil dan menengah memberikan kontribusi yang tidak dapat dikatakan sedikit dalam menunjang perekonomian negara. Di kota Jambi sendiri, peran sektor ini pada tahun 2004 cukup besar yaitu sebesar 12,8\% dari total pendapatan daerah. Usaha kecil dan menengah juga mempunyai peran yang sangat penting dalam menggerakkan roda perekonomian terutama dalam penyerapan tenaga kerja. Oleh karena itu, terpuruknya sektor ini dapat membawa dampak negatif terhadap perkembangan sektor ekonomi yang lain. Usaha kecil dan menengah di Jambi masih mungkin berkembang terutama untuk yang menggunakan bahan baku lokal dan usaha yang berbasis pertanian seperti agrobisnis. Namun perkembangan usaha perusahaan tersebut masih banyak menghadapi hambatan dan permasalahan. Salah satunya masalah yang dihadapi adalah rendahnya kualitas sumber daya manusia (SDM). Sedangkan sumber daya manusia merupakan faktor yang penting bagi setiap usaha. Hal ini didukung oleh hasil kajian Tambunan (2000) dalam Antoni (2007) yang menyatakan: "Rendahnya kualitas sumber daya manusia merupakan halangan serius bagi banyak usaha kecil di Indonesia, terutama dalam aspek-aspek entrepreneurship, manajemen, teknik produksi, pengembangan produk, engeenering design, quality control, organisasi bisnis, perakunan, data processing, teknik pemasaran, dan kajian pasar. Sedangkan semua kemahiran ini sangat diperlukan untuk mempertahankan atau memperbaiki kualitas produk, meningkatkan effisiensi dan produktivitas dalam produksi, memperluas pangsa pasar dan menembus pasar baru."

Holmes \& Nicholls (1989) dalam Fitriyah (2006) menyebutkan, bahwa permasalahan perusahaan kecil di Australia adalah terbatasnya penyediaan dan penggunaan informasi akuntansi. Informasi yang disediakan dan digunakan oleh 
perusahaan kecil hanya terbatas pada informasi yang disyaratkan/diharuskan oleh undang - undang (stationary informasion). Tambunan (2000) dalam Antoni (2007) mengungkapkan, bahwa keterbatasan dalam bidang akuntansi merupakan salah satu faktor yang menjadi sumber permasalahan dan kegagalan perusahaan kecil dan menengah. Lebih lanjut ia menguraikan, bahwa perusahaan kecil dan menengah seringkali tidak memiliki pengetahuan yang memadai dalam bidang - bidang yang sangat diperlukan dalam rangka meningkatkan kualitas produk dan efisiensi proses produksi. Salah satunya adalah kurangnya kemampuan dalam bidang akuntansi. Banyak dari pengusaha kecil yang tidak mengerti pencatatan keuangan. Ada yang sudah mulai melakukan pencatatan akuntansi, namun masih menghadapi kendala dalam menyusun laporan keuangan dan sebagainya.

Pada prinsipnya, penyelenggaraan akuntansi pada suatu perusahaan dimaksudkan untuk menyajikan informasi bagi pihak-pihak yang berkepentingan (SAK, 2007). Oleh karena itu, penerapan akuntansi pada suatu perusahaan menjadi sangat penting dalam rangka menghasilkan laporan keuangan yang memperlihatkan kondisi perusahaan dari segi finansial dan prospeknya di masa yang akan datang. Informasi yang dihasilkan dari laporan keuangan akan digunakan sebagai dasar pengambilan keputusan.

Salah satu sumber infomasi keuangan adalah laporan keuangan, di mana laporan keuangan merupakan output dari praktik akuntansi keuangan sehingga penulis menduga bahwa tingkat pengetahuan manajemen terhadap laporan keuangan juga mempunyai pengaruh terhadap praktik akuntansi.

\section{Rumusan Masalah}

Berdasarkan uraian di atas masalah dalam penelitian ini dapat dirumuskan sebagai berikut :

1. Apakah kompetensi manajer mempengaruhi praktik akuntansi keuangan yang diterapkan pada perusahaan kecil dan menengah di Kota Jambi?

2. Seberapa besar pengaruh kompetensi manajer terhadap praktik akuntansi keuangan pada perusahaan kecil dan menengah?

\section{Kerangka Pemikiran}

Undang-undang No. 9 tahun 1995 tentang usaha kecil dan menengah, Pasal 1 mendefinisikan usaha kecil adalah kegiatan ekonomi rakyat yang berskala kecil dan memenuhi kriteria kekayaan bersih atau hasil usaha tahunan serta kepemilikan sebagaimana diatur dalam undang-undang ini.

Committee for Economic Development, sebagaimana yang dikutip Harahap (1995) dalam Wijaya (2004) mendefinisikan perusahan kecil menurut sifat harus memiliki minimal dua syarat berikut : (1) Manajemennya independen, dan selalu pihak manajemennya adalah pemilik; (2) Pemilik dipegang sendiri/modal didrop secara individual atau sejumlah kecil; (3) Kegiatan usahanya bersifat lokal, dengan satu pabrik dan kantor pusat, kendatipun pasarnya tidak demikian; (4) Ukuran perusahaan relatif lebih kecil jika dilihat dari keseluruhan industri, tergantung bagaimana perusahaan itu dibandingkan dengan perusahaan terbaik dibidangnya.

Dalam peningkatan produktifitas sektoral dan pertumbuhan ekonomi, sistem pendidikan dan pelatihan yang relevan akan memberikan kontribusi yang besar terhadap produktifitas sektoral dan pertumbuhan ekonomi nasional. Hal ini disebabkan karena sistem pendidikan dan latihan merupakan sarana terpenting dalam pengembangan sumber daya manusia. Semakin tinggi tingkat relevansi pendidikan dan pelatihan, maka semakin besar kemungkinannya untuk mempersiapkan tenaga kerja yang memiliki keahlian dan keterampilan yang sesuai dengan jenis usaha maupun jenis jabatan. 
Holmes \& Nicholls (1989) dalam Fitriyah (2006) mengungkapkan bahwa pendidikan manajer atau pemilik perusahaan memiliki hubungan dengan tingkat penggunaan informasi akuntansi. Semakin tinggi tingkat pendidikan manajer maka kecenderungan mereka untuk menggunakan informasi akuntansi yang lengkap dalam pengambilan keputusan juga semakin tinggi. Hal ini disebabkan karena mereka memiliki pengetahuan dan wawasan yang luas dibandingkan dengan manajer atau pemilik yang hanya menyelesaikan pendidikan dasar atau pendidikan tingkat lanjutan pertama. Informasi akuntansi yang lengkap didapatkan dari praktik akuntansi keuangan yang baik dan benar pula. Ini berarti bahwa manajer atau pemilik perusahaan yang memiliki pendidikan lebih tinggi cendrung menerapkan akuntansi keuangan yang baik dan benar dibandingkan manajer/pemilik perusahaan yang mempunyai pendidikan lebih rendah.

Pendidikan dalam penelitian ini didefinisikan sebagai pendidikan formal yang diperoleh manajer mulai dari tingkat dasar sampai keperguruan tinggi termasuk disiplin ilmu yang dimilikinya. Ivancevich dan Matteson (1999) dalam Yulia (2004) mengatakan :" The presence or absence of various abilities and skill has an obvious relationship to job performance, manager must attemp to macth a person abilities and skill to the job requirement, this matching process is important since amount of leadership, motivation or organizational resources can make up for deficiencies in abilities or skill ..., "

Dari pernyataan tersebut terlihat bahwa terdapat hubungan yang erat antara skill dan kemampuan yang dimiliki dengan job performance sehingga manajer harus menyesuaikan kemampuan dan skill pekerja dengan bidang pekerjaan yang dimilikinya, karena keberhasilan dan kinerja dari seseorang itu sangat bergantung pada spesifikasi ilmu atau skill yang dimilikinya.

Dalam penelitian ini disiplin ilmu akuntansi dan disiplin ilmu lain yang mengandung ilmu akuntansi antara lain bisnis (manajemen) akan meningkatkan kemampuan manajer dan menerapkan akuntansi pada perusahaan yang bersangkutan. Dalam praktiknya, penempatan staf atau karyawan cendrung mempertimbangkan disiplin ilmu ini.

Selain faktor pendidikan, terdapat faktor lain yang mempengaruhi praktik akuntansi keuangan pada usaha kecil dan menengah, faktor tersebut adalah pelatihan. Menurut Kamus Besar Bahasa Indonesia (1999) pelatihan adalah proses mengajaran seseorang agar terbiasa (mampu) melakukan sesuatu; membiasakan diri (belajar). Holmes \& Nicholls (1989) dalam Fitriyah (2006) juga menunjukkan, bahwa pelatihan formal yang diikuti oleh manajer/pemilik perusahaan berpengaruh terhadap sejauh mana penggunaan informasi akuntansi. Manajer atau pemilik yang pernah mengikuti pelatihan cendrung lebih menggunakan ketiga jenis informasi akuntansi dibandingkan dengan mereka yang tidak pernah mengikuti pelatihan formal.

Demikian juga dengan pelatihan akuntansi. Semakin sering seorang manajer atau pemilik perusahaan mengikuti program pelatihan akuntansi formal, semakin besar kemungkinan mereka menggunakan informasi akuntansi untuk tujuan pengambilan keputusan. Hal ini disebabkan karena mereka mengembangkan pemahaman dan keterampilan dalam bidang akuntansi yang mereka peroleh dari pelatihan tersebut didalam mengelola usaha mereka.

Menurut Holmes \& Nicholls (1989) seperti yang dikutip oleh Fitriyah (2006) mengidentifikasi empat faktor yang berpengaruh terhadap penggunaan informasi akuntansi yaitu umur perusahaan, pendidikan pemilik perusahaan termasuk pelatihan akuntansi yang pernah diikuti oleh manajer atau pemilik perusahaan kecil dan menegah serta sektor industri di mana perusahaan beroperasi. Hasil penelitiannya menyimpulkan bahwa semakin tua suatu perusahaan terdapat kecenderungan untuk menyediakan informasi akuntansi yang tidak begitu ekstensif dibandingkan dengan perusahaan yang 
berusia muda. Pendidikan manajer juga terbukti memiliki pengaruh terhadap penggunaan informasi akuntansi. Semakin tinggi pendidikan manajer, semakin tinggi pula pengguna informasi akuntansi oleh perusahaan tersebut.

Sementara penelitian yang dilakukan oleh Yulia (2004) menyimpulkan bahwa tingkat pendidikan manajer dan tingkat kebutuhan manajemen atas laporan keuangan mempunyai pengaruh yang signifikan terhadap praktik akuntansi keuangan pada usaha kecil dan menengah. Kurangnya pemahaman pelaku bisnis pada perusahaan kecil dan menengah terhadap akuntansi sehingga mereka kesulitan dalam mengaplikasikan akuntansi. Hal ini tentu saja berakibat minimnya penerapan akuntansi pada perusahaan kecil dan menengah. Pemahaman mereka yang minim dipengaruhi oleh latar belakang dan tingkat pendidikan pimpinan serta karyawan yang menjalankan tugas-tugas pembukuan, di mana rata-rata pendidikan mereka tidak terlalu tinggi dan kalaupun tinggi tidak memiliki latar belakang pendidikan akuntansi yang memadai. Begitu juga dengan tingkat kebutuhan manajer atas laporan keuangan, semakin tinggi tingkat kebutuhan manajemen atas laporan keuangan maka semakin baik praktik akuntansi yang diterapkan.

\section{Metode Penelitian}

Penelitian ini dilakukan pada usaha kecil menengah yang telah terdaftar dan memiliki legalitas di Dinas Perindustrian, Perdagangan dan Koperasi kota Jambi baik itu sektor jasa, perdagangan dan sektor industri (manufaktur). Sedangkan objek yang diteliti adalah variabel independen $(\mathrm{X})$ yaitu kompetensi manajer dan variabel dependen $(\mathrm{Y})$ yaitu praktik akuntansi keuangan yang diterapkan pada setiap usaha kecil dan menengah tersebut.

Unit analisis dalam penelitian ini adalah usaha kecil menengah (UKM) dan manajer UKM kota Jambi yang telah terdaftar di Disperindak Kota Jambi. Populasi dari penelitian ini adalah manajer dari seluruh usaha kecil dan menengah yang telah terdaftar dan memiliki legalitas di Dinas Perindustrian, Perdagangan dan Koperasi Kota Jambi, baik sektor jasa, perdagangan dan sektor industri (manufaktur) yang berada di Kota Jambi.

Dengan menggunakan teknik sampling jenuh di mana semua anggota populasi digunakan sebagai sampel (Sugiono, 2004). Teknik ini digunakan untuk membuat generalisasi dengan kesalahan yang relatif kecil, selain itu dengan pertimbangan lama waktu yang diperlukan dalam penelitian ini serta terbatasnya dana yang tersedia, namun tanpa mengurangi akurasi dan ketajaman analisis data, sehingga 77 orang manajer UKM yang telah terdaftar di Dinas Perindustrian, Perdagangan dan Koperasi Kota Jambi dijadikan sebagai responden penelitian. Manajer UKM yang dijadikan sampel dalam penelitian ini adalah manajer puncak atau pemilik perusahaan tersebut.

Variabel independent $(\mathrm{X})$ dalam penelitian ini adalah kompetensi manajer usaha kecil dan menengah. Variabel ini diukur dalam dua dimensi yaitu a)tingkat pendidikan manajer dan b)pelatihan yang pernah diikuti manajer usaha kecil dan menengah. Dimensi tingkat pendidikan diukur dengan dua pertanyaan indiktor dengan menggunakan skala interval 1 sampai 5 , di mana 5 menunjukkan tingkat pendidikan yang tinggi dan 1 menunjukkan tingkat pendidikan yang rendah.

Sedangkan variabel dependen (Y) adalah praktik akuntansi pada usaha kecil dan menengah yang dioperasionalisasikan dalam dimensi sistem dan proses akuntansi. Dimensi sistem diukur dengan indikator struktur organisasi dan sistem' informasi akuntansi yang digunakan, sedangkan dimensi proses diukur dengan indikator kesesuaian praktik akuntansi yang diterapkan dengan standar akuntansi seperti penilaian, penyajian dan pengungkapan terutama pada pos-pos berikut: kas dan bank, piutang, persediaan, aktiva tetap, kewajiban jangka pendek, kewajiban jangka panjang, modal, pendapatan dan 
beban-beban. Variabel dependen diukur dengan menggunakan skala nominal, dimana setiap jawaban ya akan diberi skor 1 dan jawaban tidak diberi skor 0 . Selanjutnya semua indikator (sistem akuntansi dan kesesuaian pada standar) akan dijumlahkan dan dirata rata sebagai penentuan skor variabel dependen. Total skor rata - rata merupakan cerminan tingkat implementasi akuntansi pada usaha kecil dan menengah. Untuk tujuan analisis data, skor rata - rata akan dikategorikan menjadi dua kelompok yakni kelompok yang telah melakukan praktek dengan baik (kelompok 1) dan kelompok yang melakukan praktek dengan kurang baik atau masih sangat sederhana (kelompok 0). Asumsi ini digunakan untuk melihat tingkat penerapan akuntansi keuangan pada usaha kecil dan menengah. Total skor rata - rata dibawah 0,5 menggambarkan praktik akuntansi usaha kecil dan menengah yang sangat kurang dan masuk ke dalam kategori kelompok 0 dan total skor rata - rata sama dengan atau lebih dari 0,5, maka dianggap usaha kecil dan menengah tersebut telah melakukan praktik akuntansi dengan baik dan masuk kedalam kelompok 1.

Data yang dikumpulkan dianalisis dengan menggunakan statistik parametric. Pengujian data dengan metode analisis regresi diskriminan dilakukan dengan menggunakan software statistic SPSS for windows 15.0. Berdasarkan jenis variabel di atas maka model penelitian yang digunakan untuk menguji variabel yang berpengaruh terhadap praktik akuntansi pada usaha kecil dan menengah adalah sebagai berikut :

Dimana :

$$
\mathbf{Y}=\alpha+\mathbf{B}_{1} \mathbf{X}_{1}+\mathbf{e}
$$

$\mathrm{Y} \quad=$ Praktik akuntansi pada usaha kecil dan menengah di Kota Jambi

$\alpha \quad=$ Konstanta

$B_{1} \quad=$ Koefisien regresi diskriminan

$\mathrm{X} 1=$ Kompetensi manajer perusahaan kecil dan menengah

$\mathrm{e}=$ Error atau variasi gangguan / variabel lain yang tidak terdefenisikan

Sebelum data diolah akan dilakukan pengujian validitas dan reabilitas, serta uji asumsi analisis diskriminan di mana analisis diskriminan berasumsi bahwa data berasal dari multivariate normal distribution dan matrik kovarian kedua kelompok adalah sama.

Selain melakukan pengujian validitas dan reliabilitas, dilakukan juga uji asumsi analisis diskriminan. Pengujian ini dimaksudkan untuk mengetahui bahwa model regresi diskriminan yang digunakan tidak bias dan valid sehingga tidak terjadi pelanggaran terhadap asumsi tersebut.

\section{Hasil Penelitian Dan Pembahasan}

Dari hasil perhitungan diperoleh hasil sebagai berikut :

Tabel 5

Hasil Pengujian Reliabilitas Variabel Kompetensi Manajer

\begin{tabular}{|c|c|c|}
\hline Jumlah Butir Pertanyaan & Koefisien Reliabilitas & Keterangan \\
\hline 4 & 0,750 & Reliabel \\
\hline
\end{tabular}

Sumber: Data Olahan

Tabel 6

Hasil Pengujian Reliabilitas Variabel Praktik Akuntansi

\begin{tabular}{|c|c|c|}
\hline Jumlah Butir Pertanyaan & Koefisien Reliabilitas & Keterangan \\
\hline 63 & 0,955 & Reliabel \\
\hline
\end{tabular}

Sumber: Data Olahan

Dari dua tabel di atas terlihat bahwa reliabilitas variabel kompetensi manajer melebihi Cronbach alpha yaitu sebesar 0,750, sedangkan reliabilitas variabel praktik akuntansi sebesar 0,955 sehingga dapat disimpulkan bahwa alat ukur dapat dipercaya dan handal. 
besar pimpinan usaha kecil dan menengah tersebut tidak memiliki kemampuan yang memadai di bidang akuntansi.

Pelatihan Akuntansi diukur berdasarkan intensitas pelatihan dan lama waktu yang pernah diikuti manajer. Dari 77 responden, 54 orang $(70,13 \%)$ diantaranya tidak pernah mengikuti pelatihan akuntansi. Sementara jumlah manajer yang pernah mengikuti pelatihan akuntansi hanya sebanyak 23 orang $(29,87 \%)$. Dari 23 orang manajer yang pernah mengikuti pelatihan akuntansi hanya 15 orang yang mengikuti pelatihan akuntansi sebanyak 1 kali, dan 8 orang hanya mengikuti pelatihan akuntansi sebar selengkapnya bisa dilihat dari Tabel 10 berikut :

Tabel 10

Intensitas Pelatihan yang Pernah Diikuti Manajer Usaha Kecil dan Menengah

\begin{tabular}{|c|c|c|}
\hline \multirow{2}{*}{ Jumlah Pelatihan } & \multicolumn{2}{|c|}{ Jumlah Responden } \\
\cline { 2 - 3 } & Jumlah & $\%$ \\
\hline Tidak Pernah & 54 & $70,13 \%$ \\
1 kali & 15 & $19,48 \%$ \\
3 kali & 8 & $10,39 \%$ \\
5 kali & 0 & $0 \%$ \\
Lebih dari 5 kali & 0 & $0 \%$ \\
\hline TOTAL & 77 & $100 \%$ \\
\hline
\end{tabular}

Sumber: Data Olahan

Untuk lama waktu pelatihan yan menit dan 4 orang $(5,19 \%)$ manajer menjawab manajer menjawab selama $190 \mathrm{~s} / \mathrm{d} 280$ me dapat dilihat dalam tabel 11

selama $360 \mathrm{~s} / \mathrm{d} 420$ menit. Selengkapny Tabel 11

Lama Waktu Pelatihan yang Pernah Diikuti Manajer Usaha Kecil dan Menengah

\begin{tabular}{|c|c|c|}
\hline \multirow{2}{*}{ Lama Waktu } & \multicolumn{2}{|c|}{ Jumlah Responden } \\
\cline { 2 - 3 } & Jumlah & $\%$ \\
\hline Tidak Menjawab & 54 & $70,13 \%$ \\
30 s/d 45 menit & 0 & $0 \%$ \\
45 s/d 190 menit & 0 & $0 \%$ \\
190 s/d 280 menit & 19 & $24,68 \%$ \\
280 s/d 360 menit & 0 & $0 \%$ \\
360 s/d 420 menit & 4 & $5,19 \%$ \\
\hline TOTAL & 77 & $\mathbf{1 0 0} \%$ \\
\hline
\end{tabular}

Sumber : Data Olahan

Variabel praktik akuntansi pada usaha kecil dan menengah yang dioperasionalisasikan dalam dimensi sistem dan proses akuntansi. Jika dilihat dari kelengkapan laporan keuangan yang dibuat, hanya ada 3 UKM $(3,90 \%)$ yang membuat laporan keuangan secara lengkap (kelima laporan dibuat), 16 UKM (20,78\%) yang hanya membuat satu jenis laporan keuangan, sedangkan sebanyak 44 UKM $(57,14 \%)$ yang tidak membuat laporan sama sekali. Rincian mengenai kelengkapan jenis laporan yang dsajikan dapat dilihat pada Tabel 12 
Tabel 12

Kelengkapan Jenis laporan

\begin{tabular}{|c|c|c|}
\hline Jenis Laporan yang dibuat & Jumlah Perusahaan & $\%$ \\
\hline Tidak membuat Laporan & 44 & $57,14 \%$ \\
Satu jenis laporan & 16 & $20,78 \%$ \\
Dua jenis laporan & 7 & $9,09 \%$ \\
Tiga jenis laporan & 1 & $1,30 \%$ \\
Empat jenis laporan & 6 & $7,79 \%$ \\
Lima jenis Laporan (Lengkap) & 3 & $3,90 \%$ \\
\hline Total & 77 & $100 \%$ \\
\hline
\end{tabular}

Sumber : Data Olahan

Keterangan Tabel :

1. Satu jenis laporan maksudnya hanya membuat salah satu dari laporan keuangan misalnya Neraca saja atau Laporan laba/rugi saja.

2. Dua jenis laporan maksudnya hanya membuat dua laporan dari lima yang ada, misalnya Neraca dan Laporan laba/rugi.

3. Tiga jenis laporan maksudnya membuat tiga laporan misalnya Neraca, Laporan laba/rugi dan laporan perubahan modal.

4. Empat jenis laporan maksudnya membuat empat laporan misalnya, Neraca, Laporan laba/rugi, Laporan perubahan modal, dan Laporan arus kas.

5. Lima jenis laporan maksudnya perusahaan membuat keseluruhan laporan keuangan.

Dan jika ditinjau dari keseluruhan praktik akuntansi yang diterapkan pada usaha kecil dan menengah yang dijadikan sampel dalam penelitian ini, sebanyak 64 UKM $(83,12 \%)$ memperoleh rata - rata skor dibawah 0,5 sehingga masuk dalam kategori kelompok UKM 0 yang berarti UKM tersebut masih memiliki praktik akuntansi yang kurang atau dengan kata lain praktik akuntansi yang diterapkan masih sangat sederhana. Sedangkan sebanyak 13 UKM (16,88 \%) memperoleh rata - rata skor diatas atau sama dengan 0,5 sehingga masuk dalam kategori kelompok UKM 1 yang berarti bahwa UKM tersebut memiliki kriteria baik dalam menerapkan praktik akuntansi keuangan. Seperti yang terlihat pada tabel 13

Tabel 13

Tingkat Praktik Akuntansi Keuangan pada Usaha Kecil dan Menengah

\begin{tabular}{|c|c|c|}
\hline Kriteria & Jumlah UKM & $\%$ \\
\hline 0 ( Kurang baik ) & 64 & $83,12 \%$ \\
\hline 1 (Baik) & 13 & $16,88 \%$ \\
\hline Total & 77 & 100 \\
\hline
\end{tabular}

Sumber : Data Olahan

\section{Analisis data penelitian}

Uji asumsi diskriminan

A. Uji asumsi Multivariate Normal Distribution

Asumsi multivariate normal distribution penting untuk menguji signifikansi dari variabel diskriminator dan fungsi diskriminan. Jika data tidak normal secara multivariate, maka secara teori uji signifikansi menjadi tidak valid. Hasil klasifikasi menurut teori juga dipengaruhi oleh multivariate normal distribution. Untuk menguji apakah ada perbedaan secara signifikan antara kedua kelompok UKM dapat menggunakan wilk's L test statistik, 
dan untuk menguji signifikansi nilai wilk's L maka dikonversikan kedalam $\mathrm{F}$ ratio. Semaki kecil nilai wilk's L, maka semakin besar kemungkinan adanya perbedaan rata rata populasi. Untuk menguji signifikan statistik dari fungsi diskriminan digunakan multivariate test yaitu uji wilk's lamda yang dapat diaproksimasi dengan statistik chisquare.

Dilihat dari test statistik wilk's L jelas ada perbedaan secara signifikan yaitu sebesar 0,759 dan signifikan pada 0,0000. Hal ini menunjukkan bahwa variabel kompetensi manajer dapat digunakan untuk membentuk variabel diskriminan atau dengan kata lain variabel kompetensi manajer mampu membedakan (mendiskriminate) praktik akuntansi, hal ini dilihat dari nilai wilk's lambda yang signifikan dibawah 0,05 .

Tabel 14

Tests of Equality of Group Means

\begin{tabular}{|l|r|r|r|r|r|}
\hline & $\begin{array}{c}\text { Wilks' } \\
\text { Lambda }\end{array}$ & F & df1 & df2 & Sig. \\
\hline $\begin{array}{l}\text { KOMPETENSI_M } \\
\text { GT }\end{array}$ & .759 & 23.840 & 1 & 75 & .000 \\
\hline
\end{tabular}

Sumber : Data Olahan

Dan jika dilihat dari besarnya nilai wilk's lamda sebesar 0,759 atau sama dengan chi-square 20,563 dan signifikan pada 0,0000, maka dapat disimpulkan bahwa fungsi diskriminan signifikan secara statistik yang berarti nilai means score diskriminan untuk kedua kelompok praktik akuntansi berbeda secara signifikan.

Tabel 15

Wilks' Lambda

\begin{tabular}{|l|r|r|r|r|}
\hline $\begin{array}{l}\text { Test of } \\
\text { Function(s }\end{array}$ & $\begin{array}{c}\text { Wilks' } \\
\text { Lambda }\end{array}$ & Chi-square & df & Sig. \\
\hline 1 & .759 & 20.563 & & 1 \\
\hline
\end{tabular}

Sumber : Data Olahan

\section{B. Matrik kovarian}

Analisis diskriminan berasumsi bahwa terdapat homoginitas matrik covariance antar groups. Untuk mengetahui adanya homoginitas matrik covariance dapat dilihat dari hasil uji box's M, jika nilai F signifikan dibawah 0.05, maka dapat disimpulkan bahwa matrik covariance antar group memang berbeda dan hal ini menyalahi asumsi diskriminan. Pada tabel test results berikut terlihat bahwa hasil uji box's M menunjukkan bahwa nilai $F$ sebesar 3,112 dan signifikan pada 0,078 dan probabilitas ini diatas 0,05 maka dapat disimpulkan bahwa matrik covariance antar group tidak berbeda dan hal ini memenuhi asumsi diskriminan bahwa matrik covariance kedua kelompok adalah sama.

Tabel 16

Test Results

\begin{tabular}{|ll|r|}
\hline Box's M & & 3.199 \\
F & Approx & 3.112 \\
& df1 & 1 \\
& df2 & 3661.427 \\
Sig. & .078 \\
\hline
\end{tabular}

Sumber : Data Olahan 
Analisis Diskriminan berikut

Dari hasil pengolahan data dengan analisis diskriminan diperoleh hasil sebagai

Tabel 17

Analisis Diskriminan

\begin{tabular}{|ll|r|r|r|r|}
\hline $\begin{array}{l}\text { PRAKTIK } \\
\text { AKT }\end{array}$ & \multicolumn{1}{c|}{$\begin{array}{c}\text { Mean } \\
\text { Unweighte } \\
\text { d }\end{array}$} & $\begin{array}{c}\text { Std. } \\
\text { Deviation }\end{array}$ & \multicolumn{2}{|c|}{ Valid N (listwise) } \\
\hline .00 & $\begin{array}{l}\text { KOMPETENS } \\
\text { KOMweighte } \\
\text { d }\end{array}$ & 1.6563 & .73934 & 64 & Weighted \\
1.00 & $\begin{array}{l}\text { I_MGT } \\
\text { KOMPETENS }\end{array}$ & 2.8462 & 1.06819 & 13 & 13.000 \\
Total & $\begin{array}{l}\text { I_MGT } \\
\text { KOMPETENS }\end{array}$ & 1.8571 & .91356 & 77 & 77.000 \\
\hline
\end{tabular}

Sumber : Data Olahan

Berdasarkan data primer yang diolah diketahui ada 64 responden yang melakukan praktik akuntansi kurang baik, karena memiliki rata - rata berkisar antara 1 2 sehingga 64 responden tersebut masuk kedalam kategori kelompok 0. Sedangkan 13 responden yang memiliki rata - rata $\geq 2$ masuk kedalam kelompok 1 , dimana responden tersebut telah melakukan praktik akuntansi yang baik.

Sehingga persamaan dikriminan yang terbentuk adalah :

$$
Y=-2,318+1,248 \times 1
$$

Dimana, $\quad \mathrm{Y}=$ Praktik akuntansi pada usaha kecil dan menengah

X $1=$ Kompetensi manajer pada usaha kecil dan menengah

Dari hasil persamaan diskriminan yang dihasilkan, maka ternyata variabel kompetensi manajer mempunyai pengaruh positif terhadap praktik akuntansi yang diterapkan pada usaha kecil menengah tersebut, sehingga semakin tinggi kompetensi manajer maka semakin baik praktik akuntansi yang diterapkan pada UKM tersebut.

Untuk menguji seberapa besar dan berarti perbedaan antara kedua kelompok tersebut dapat dilihat dari nilai square canonical correlation $\left(\mathrm{CR}^{2}\right)$ yang identik dengan nilai $R^{2}$ pada regresi yaitu untuk mengukur variasi antara kedua kelompok yang dapat dijelaskan oleh variabel diskriminannya (Ghozali, 2005). Jadi nilai $\mathrm{CR}^{2}$ tersebut dapat dipergunakan untuk mengukur seberapa kuat fungsi diskriminannya.

Dari output table Eigenvalues menunjukkan bahwa besarnya canonical correlation (CR) adalah 0,491 atau besarnya Square canonical correlation $\left(\mathrm{CR}^{2}\right)$ adalah $(0,491)^{2}=0,241$ atau sebesar $24,1 \%$. Sehingga dapat disimpulkan bahwa kelompok UKM yang termasuk dalam praktik akuntansi yang baik dan yang kurang baik dapat dijelaskan oleh variabel kompetensi manajer sebesar $24,1 \%$ dan sisanya $75,9 \%$ dijelaskan oleh variabel diluar variabel tersebut.

Tabel 18

Eigenvalues

\begin{tabular}{|l|r|c|c|r|}
\hline Function & Eigenvalue & $\begin{array}{c}\% \text { of } \\
\text { Variance }\end{array}$ & $\begin{array}{c}\text { Cumulative } \\
\%\end{array}$ & $\begin{array}{c}\text { Canonical } \\
\text { Correlation }\end{array}$ \\
\hline 1 & $.318(\mathrm{a})$ & 100.0 & 100.0 & .491 \\
\hline
\end{tabular}

Sumber : Data Olahan 


\section{Simpulan}

Berdasarkan hasil penelitian yang telah diuraikan pada bab sebelumnya, maka dapat ditarik kesimpulan sebagai berikut :

1. Kompetensi manajer mempunyai pengaruh positif terhadap praktik akuntansi pada usaha kecil dan menengah.

2. Dalam penelitian ini pengaruh kompetensi manajer tidak terlalu besar. Sehingga dapat disimpulkan bahwa kelompok UKM yang termasuk dalam praktik akuntansi yang baik dan yang kurang baik dapat dijelaskan oleh kompetensi manajer sebesar $24,1 \%$ dan sisanya $75,9 \%$ dijelaskan oleh faktor lain diluar faktor tersebut.

\section{Saran}

Penelitian ini masih banyak memiliki keterbatasan, diantaranya adalah jumlah sampel yang terlalu kecil sehingga hasil yang diperoleh kurang dapat mewakili fakta yang terjadi dilapangan, selain itu dari segi pemahaman responden yang masih kurang sehingga menyulitkan dalam pengisian kuisioner disamping itu alasan kesibukan dari para responden atau pemilik usaha sehingga mereka mendelegasikan pengisian kuesioner kepada bawahannya.

Sehingga saran untuk penelitian selanjutnya antara lain :

a. Bagi peneliti berikutnya diharapkan dapat menguji faktor - faktor lain yang dapat mempengaruhi praktik akuntansi pada usaha kecil dan menengah.

b. Subjek penelitian ini hanya terbatas pada usaha kecil dan menengah yang terdaftar pada Dinas Perindustrian, Perdagangan dan Koperasi, sehingga bagi peneliti berikutnya sebaiknya dapat memperluas subjek penelitian sehingga dapat meningkatkan jumlah responden penelitian.

\section{Daftar Pustaka}

Antoni. 2007. Pengembangan Kinerja Usaha kecil Ditinjau dari Aspek Pelatihan dan Pengalaman Kerja pengusaha. http://www.bunghatta.info/content.php?article. 198

Badan Pusat Statistik. 1998. Profil Usaha Kecil dan Menengah Sektor industri Kecil dan Kerajinan Rumah Tangga Indonesia. BPS. Jakarta.

Fitriyah, Hadiyah. 2006. Faktor-faktor yang Mempengaruhi Penggunaan Informasi Akuntansi Pada Perusahaan Kecil di Sidoharjo. Tesis Sarjana pada Fakultas Ekonomi Universitas Airlangga, Surabaya. http://www.hadiyahfitriyah.info/content.

Ghozali, Imam . 2005. Aplikasi Analisis Multivariate dengan Program SPSS. Badan Penerbit - UNDIP. Semarang.

Hendriksen, Eldon S. dan Van Bred, Michael F. Alih Bahasa Herman Wibowo.2000. Teori Akuntansi. INTERAKSA. Batam.

Ikatan Akuntan Indonesia. 2007. Standar Akuntansi Keuangan. Salemba Empat. Jakarta.

Kementrian KUKM. 2007. Indikator Makro Ekonomi Usaha Kecil dan Menengah Tahun 2006. www.depkop.go.id

Sugiono. 2004. Metode Penelitian Bisnis. Bina aksara. Jakarta.

Suprapto, H. 2007. Pengaruh Kompetensi Manajer Proyek Terhadap Kinerja Biaya Pada Proyek Konstruksi. Vol.2.ISSN:1858-2559.

Tambunan, Tulus. 2001. Peranan Usaha Kecil dan Menengah bagi Perekonomian Indonesia dan Prospeknya. Majalah Usahawan No. 7 Juli. Edisi XXXI, Juli, Hal. 3-15. 
Umar, Husein. 2002. Reasearch Methods in Finance and Banking. PT.Gramedia Pustaka Utama. Jakarta

Umar, Husein. 2001. Riset akuntansi. PT. Gramedia Pustaka Utama. Jakarta Undang-undang No.9 Tahun 1995 Tentang Usaha Kecil dan Menengah.

Yulia, Vera. 2004. Pengaruh Tingkat Pendidikan Manajer dan Kebutuhan Manajer atar Laporan keuangan terhadap Praktek Akuntansi keuangan Pada Usaha Kecil dan Menengah. Skripsi Sarjana pada Fakultas Ekonomi Universitas Andalas. Padang.

Yadiati, Wiwin dan Ilham Wahyudi. 2006. Pengantar Akuntansi. Edisi Revisi. Kencana. Jakarta. 